\title{
Ocena rządowego projektu ustawy o zmianie ustawy o postępowaniu egzekucyjnym w administracji oraz niektórych innych ustaw ${ }^{1}$
}

\begin{abstract}
Zdaniem autorki opinii nowelizacja zawiera regulacje usprawniające oraz zwiększające efektywność postępowania egzekucyjnego w administracji. Wprowadza m.in. nową instytucję w tym postępowaniu, tj. sprzedaż ruchomości przez zobowiązanego za zgodą organu egzekucyjnego oraz dobrowolną zapłatę zobowiązanego. Regulacje dotyczące podziału kwoty uzyskanej z egzekucji administracyjnej dostosowują procedurę egzekucyjną do wymogów prawa unijnego. Do zmian korzystnych dla zobowiązanego należy wyłączenie z egzekucji m.in. świadczeń „500+”, na wzór regulacji zawartej w przepisach dotyczących egzekucji sądowej.
\end{abstract}

Słowa kluczowe: administracja publiczna, ocena skutków regulacji, postępowanie egzekucyjne, projekt ustawy

Evaluation of the government's Bill on Amending the Act on Enforcement Proceedings in Administration and Some Other Acts: In the opinion of the author, the amendment contains a number of regulations improving and increasing the effectiveness of enforcement proceedings in administration. It introduces, among others, a new institution in such proceedings, i.e. sale of movables by the debtor with the consent of the enforcement authority and voluntary payment of the debtor. Rules on the distribution of the amount obtained from administrative enforcement adjust the enforcement procedure to the requirements of the EU law. One of the changes beneficial to the debtor is the exclusion from enforcement of, among others, "500+" benefits, following the example of the regulation contained in the provisions on court enforcement.

Keywords: public administration, impact assessment, executive proceedings, bill

Doktor nauk prawnych, ekspert ds. legislacji BAS - beata.binkowskaartowicz@sejm.gov.pl • https://orcid.org/0000-0002-9172-5458

\section{Przedmiot projektu}

Przedmiotem projektu jest ustawa o zmianie ustawy o postępowaniu egzekucyjnym $\mathrm{w}$ administracji ${ }^{2}$ oraz niektórych innych ustaw (dalej: ustawa zmieniająca lub projekt). Projekt dotyczy m.in. elektronicznego doręczania organowi egzekucyjnemu tytułu wykonawczego, trybu rozpatrywania zarzutów i wniosków

1 Ocena rządowego projektu ustawy o zmianie ustawy o postępowaniu egzekucyjnym $w$ administracji oraz niektórych innych ustaw (nr druku sejmowego 3753) sporządzona 14 sierpnia 2019 r. na zlecenie zastępcy Szefa Kancelarii Sejmu; BAS-WAP 1699/19.

2 Ustawa z 17 czerwca 1966 r. o postępowaniu egzekucyjnym w administracji, t.j. Dz.U. 2018, poz. 1314, ze zm.; dalej: u.p.e.a. 
o umorzenie postępowania egzekucyjnego, procedury dochodzenia $\mathrm{z}$ majątku wspólnego zobowiązanego i jego małżonka oraz dłużnika rzeczowego, zbiegów egzekucji, egzekucji z ruchomości przez wprowadzenie nowej formy sprzedaży ruchomości przez zobowiązanego za zgodą organu egzekucyjnego, egzekucji z nadpłaty lub zwrotu podatku, wprowadzenia możliwości korzystania z terminali płatniczych przy egzekucji z pieniędzy, elektronizacji egzekucji z rachunku bankowego prowadzonego przez spółdzielczą kasę oszczędnościowo-kredytową oraz z praw z instrumentów finansowych zapisanych na rachunkach papierów wartościowych lub innych rachunkach prowadzonych przez banki, wykonywania przez naczelników urzędów skarbowych postanowień o zabezpieczeniu majątkowym wydanych na podstawie procedury karnej i ograniczenia rozpatrywania przez naczelników urzędów skarbowych środków zaskarżenia podejrzanego, które rozpatruje prokurator lub sąd w postępowaniu karnym, zmiany kolejności zaspokojenia należności celnych.

Zamiarem projektodawcy było m.in. uproszczenie i usprawnienie postępowania egzekucyjnego, a także dostosowanie przepisów do zalecenia Dyrekcji Generalnej ds. Budżetu Komisji Europejskiej, zawartego w sprawozdaniu służb Komisji nr 17-22-1 w sprawie kontroli tradycyjnych zasobów własnych przeprowadzonej w Polsce w dniach od 10-13 października 2017 r.

Vacatio legis ustawy zmieniającej wynosi 9 miesięcy od dnia ogłoszenia, z wyjątkiem:

- art. 8, który wchodzi w życie z dniem 1 stycznia 2020 r.,

- art. 1 pkt 48-51 i 87 projektu, art. 2 pkt 10 i 12 projektu, art. 4 projektu, art. 9 projektu, art. 11 ust. 2 pkt 2 projektu i art. 12 ust. 2 pkt 1 projektu, które wchodzą w życie po upływie 12 miesięcy od dnia ogłoszenia,

- art. 1 pkt 12 projektu w zakresie art. $26 \mathrm{c} \$ 5$ pkt 2 lit. b u.p.e.a. oraz pkt 13 projektu w zakresie art. $26 \mathrm{ca} \$ 3$ pkt 2 lit. b u.p.e.a., które wchodzą w życie po upływie 18 miesięcy od dnia ogłoszenia,

- art. 1 pkt 54 projektu, art. 2 pkt 16 lit. b projektu, art. 11 ust. 2 pkt 4 projektu oraz art. 12 ust. 2 pkt 3 projektu, które wchodzą w życie po upływie 24 miesięcy od dnia ogłoszenia (art. 27 ustawy zmieniającej).

\section{Adresat projektu}

Adresatami projektowanej ustawy zmieniającej staną się:

- organy egzekucyjne, o których mowa w art. la pkt 7 u.p.e.a.,

- wierzyciele, o których mowa w art. 1a pkt 13 u.p.e.a.,

- dłużnicy zajętych wierzytelności, o których mowa w art. 1a pkt 3 u.p.e.a.,

- komornicy sądowi,

- małżonkowie zobowiązanych (w zakresie majątku wspólnego),

- zobowiązani, o których mowa w art. 1a pkt 20 u.p.e.a., 
- sądy administracyjne,

- dłużnicy rzeczowi,

- zobowiązani.

\section{Ocena skutków prawnych przyjęcia projektu}

Projekt uwzględnia zalecenie Dyrekcji Generalnej ds. Budżetu Komisji Europejskiej, zawarte w sprawozdaniu służb Komisji nr 17-22-1 w sprawie kontroli tradycyjnych zasobów własnych przeprowadzonej w Polsce w dniach 10-13 października 2017 r., dotyczące przyznania pierwszeństwa zaspokojenia należności celnych, stanowiących koszty własne Unii Europejskiej, przed kosztami egzekucyjnymi i kosztami upomnienia powstałymi w związku z dochodzeniem tych należności. W omawianym projekcie zaproponowano zmianę przepisów regulujących rozliczenie kwoty uzyskanej z egzekucji. Należności celne będą zaspokajane w kolejności przewidzianej dla należności, do których stosuje się przepisy działu III Ordynacji podatkowej, oraz należności z tytułu składek na ubezpieczenie społeczne, przed kosztami egzekucyjnymi i kosztami upomnienia naliczonymi w związku z egzekucją należności. Odsetki od należności celnych zaspokajane będą po zaspokojeniu wymienionych kosztów egzekucyjnych i kosztów upomnienia.

Pozytywna z punktu widzenia wierzyciela wydaje się zmiana, zgodnie z którą upomnienie (o którym mowa w art. $15 \$ 1$ u.p.e.a.) zawierające wezwanie do wykonania obowiązku administracyjnego może również zawierać zawiadomienie o zagrożeniu ujawnieniem w Rejestrze Należności Publicznoprawnych z art. 18c $\$ 1$ u.p.e.a. (art. 18c \$2 u.p.e.a.). Rozwiązanie to pozwoli obniżyć koszty realizacji ustawowego obowiązku informacyjnego.

Nowelizacja zmienia obowiązujący model zarzutów w postępowaniu egzekucyjnym w administracji. Pozytywne z punktu widzenia zobowiązanego jest zniesienie dotychczasowego, siedmiodniowego terminu do złożenia zarzutu w sprawie egzekucji administracyjnej i wprowadzenie możliwości składania tego środka odwoławczego w różnych terminach (uzależnionych od wyegzekwowania obowiązku, wykonania obowiązku oraz doręczenia postanowienia o umorzeniu postępowania egzekucyjnego - art. 33 u.p.e.a.), przy czym jedynie zarzut wniesiony w terminie 7 dni od dnia doręczenia tytułu wykonawczego będzie skutkował zawieszeniem postępowania (art. $35 \$ 1$ u.p.e.a.). Intencji ograniczenia czasowego tego skutku należy upatrywać w dążeniu do zapewnienia szybkości postępowania egzekucyjnego. W projekcie przewidziano także skrócenie postępowania w zakresie rozpatrywania zarzutów egzekucyjnych. Zgodnie z proponowaną regulacją, rozpatrywanie zarzutów będzie należało do wierzyciela, podczas gdy obecnie obowiązująca regulacja obliguje organ egzekucyjny do rozpatrzenia zarzutów po uprzednim uzyskaniu stanowiska wierzyciela (art. $34 \$ 1$ u.p.e.a. w obowiązującym brzmieniu). 
Wprowadzenie zasady, zgodnie z którą organ egzekucyjny stwierdza uchybienie terminu do wniesienia podania (skargi, wniosku) w drodze postanowienia, na które służy zażalenie, a następnie - skarga do sądu administracyjnego (art. 17 $\$ 1$ c u.p.e.a.), należy jednoznacznie ocenić pozytywnie z punktu widzenia pozycji zobowiązanego. Rozwiązanie to ujednolici także praktykę organów egzekucyjnych.

Korzystna dla małżonka zobowiązanego będzie możliwość uzyskania - na wniosek - od organu egzekucyjnego informacji m.in. o wysokości egzekwowanej należności pieniężnej (art. 27e $\$ 4$ u.p.e.a.). Jednak w celu ochrony interesów małżonka zobowiązanego ustawodawca mógłby rozważyć wprowadzenie obowiązku informowania $z$ urzędu tego małżonka o egzekucji skierowanej do majątku wspólnego w przypadku, gdy organowi z urzędu znane są dane tego małżonka. Pozytywnie należy również ocenić wprowadzenie uprawnienia dla małżonka zobowiązanego do złożenia sprzeciwu w zakresie dotyczącym majątku wspólnego (art. 27f $\$ 1$ u.p.e.a.) oraz przyznanie małżonkowi zobowiązanego praw zobowiązanego w egzekucji z majątku wspólnego (art. $27 \mathrm{~g} \$ 1$ u.p.e.a.). Również trafne wydaje się wprowadzenie obowiązku poinformowania zobowiązanego o wniesieniu sprzeciwu przez jego małżonka (art. $27 \mathrm{f} \$ 4$ u.p.e.a.) oraz o sposobie jego rozstrzygnięcia (art. $27 f \$ 6$ u.p.e.a.). Należy bowiem zauważyć, że w sytuacji, gdy ewentualne postanowienie oddalające sprzeciw zostanie zaskarżone do sądu administracyjnego przez małżonka zobowiązanego, zobowiązanemu będzie przysługiwał wniosek o dopuszczenie do udziału w postępowaniu sądowoadministracyjnym jako uczestnik na prawach strony (art. $33 \$$ la ustawy z 30 sierpnia 2002 r. - Prawo o postępowaniu przed sądami administracyjnymi; t.j. Dz.U. 2018, poz. 1302, dalej: p.p.s.a.).

Korzystna z punktu widzenia organu egzekucyjnego jest zmiana polegająca na rozszerzeniu możliwości sposobu wszczęcia egzekucji (art. $26 \S 5$ u.p.e.a.) przez podpisanie protokołu zajęcia ruchomości przez pracownika obsługującego organ egzekucyjny lub przez wpis w księdze wieczystej o wszczęciu egzekucji z nieruchomości lub też przez złożenie wniosku o wpis o wszczęciu egzekucji z nieruchomości do zbioru dokumentów. Regulacja ta umożliwi zajęcie przed doręczeniem tytułu wykonawczego, co może pozwolić na uniknięcie próby udaremnienia egzekucji.

Z punktu widzenia organów egzekucyjnych pozytywnie należy ocenić ujęcie w tytule wykonawczym numeru REGON, ponieważ np. dłużnik zajętej wierzytelności może posiadać ten numer, nie dysponując jednocześnie innym numerem identyfikującym zobowiązanego (art. $27 \$ 1$ pkt 2 u.p.e.a.).

Korzystne dla dłużnika rzeczowego (czyli nabywcy rzeczy obciążonej zastawem skarbowym lub hipoteką przymusową) jest przyznanie mu prawa do złożenia sprzeciwu oraz do uczestnictwa w egzekucji tej rzeczy na prawach zobowiązanego (art. 27i \$ 3, art. 27j u.p.e.a.). Należy zwrócić uwagę, że w sytuacji, gdy ewentualne postanowienie oddalające sprzeciw dłużnika rzeczowego zostanie 
zaskarżone do sądu administracyjnego przez dłużnika rzeczowego, zobowiązanemu będzie przysługiwał wniosek o dopuszczenie do udziału w postępowaniu sądowoadministracyjnym jako uczestnik na prawach strony (art. $33 \$ 1$ a p.p.s.a.).

Z uwagi na szybkość postępowania egzekucyjnego trafne wydaje się rozwiązanie, zgodnie z którym wierzyciel jest zobowiązany do niezwłocznego poinformowania organu egzekucyjnego o faktach mających szczególne znaczenie dla postępowania (art. 32aa u.p.e.a.). Regulacja ta jest również korzystna dla zobowiązanego, zwłaszcza w zakresie informacji dotyczących zdarzeń powodujących zawieszenie lub umorzenie postępowania egzekucyjnego.

Należy ocenić pozytywnie propozycję zawartą w art. 37c $\$ 1$ zdanie pierwsze u.p.e.a., zgodnie z którą: rozporządzenie rzecza lub prawem majątkowym po ich zajęciu nie ma wpływu na dalsza egzekucję z tej rzeczy lub prawa majątkowego. Zgodnie ze zdaniem trzecim tego przepisu, czynności egzekucyjne podjęte $w$ ramach tej egzekucji sa skuteczne wobec zobowiąanego i nabywcy rzeczy lub prawa majątkowego. Regulacje powyższe uniemożliwią próbę uniknięcia egzekucji. Jednocześnie ochronę nabywcy rzeczy zapewnia zdanie drugie omawianego przepisu, umożliwiające nabywcy uczestnictwo w egzekucji na prawach zobowiązanego.

Pozytywnie z uwagi na zapewnienie zasady szybkości postępowania należy ocenić kompetencję organu egzekucyjnego do wystąpienia w przypadku śmierci zobowiązanego do wierzyciela o zajęcie stanowiska, czy obowiązek jest ściśle związany ze zobowiązanym (art. $56 \$ 1$ c u.p.e.a.).

Instytucję sprzedaży ruchomości przez zobowiązanego za zgodą organu egzekucyjnego (art. 104a u.p.e.a.) należy ocenić pozytywnie. Sprzedaż taka może usprawnić egzekucję i doprowadzić do uzyskania najwyższej ceny, co pozostaje zarówno w interesie zobowiązanego, jak też organu egzekucyjnego. Omawiana forma uzyskania środków na pokrycie egzekwowanych należności nie jest sprzedażą egzekucyjną. Z uwagi na uznaniowość postanowienia organu egzekucyjnego co do zgody na sprzedaż, rozstrzygnięcie to słusznie zostało poddane kontroli sądu administracyjnego. Dostrzeżenia wymaga, że w ewentualnej sprawie ze skargi na postanowienie odmawiające zgody na sprzedaż ruchomości przez zobowiązanego organ egzekucyjny, kierując się dyrektywą szybkości postępowania egzekucyjnego, może złożyć wniosek o rozpoznanie tej sprawy w postępowaniu uproszczonym, to jest bez wyznaczania rozprawy (art. 119 pkt 3 p.p.s.a.).

Doprecyzowanie właściwości dyrektora izby skarbowej, który rozpoznaje spór kompetencyjny między organami egzekucyjnymi, usuwa dotychczasową sprzeczność w art. $63 \$ 2$ u.p.e.a. Eliminuje to możliwość ewentualnego dodatkowego negatywnego sporu kompetencyjnego na poziomie dyrektorów izb skarbowych.

Instytucję dobrowolnej zapłaty zobowiązanego (art. 67e u.p.e.a.) należy ocenić pozytywnie w świetle wyroku Trybunału Konstytucyjnego z 28 czerwca 2016 r., sygn. akt. SK 31/14. W wyroku tym Trybunał w kontekście opłat egzekucyjnych zwrócił uwagę, że nie należy zniechęcać dłużników (w rozumieniu ustawy o po- 
stępowaniu egzekucyjnym w administracji - zobowiązanych) do dobrowolnego, choć spóźnionego - skoro sprawa dojrzała do egzekucji - regulowania zobowiązań. Należy także podzielić przedstawiony w opinii Rady Legislacyjnej ${ }^{3}$ pogląd, że instytucja ta pozostawia ochrone wierzyciela, (zapłata obejmuje należność pieniężną, odsetki, koszty upomnienia i koszty egzekucyjne), z drugiej jednak strony nie zmusza organów Państwa do stosowania środków przymusu, co jest w tej sytuacji po prostu zbędne, a zobowiązanego chroni przed negatywnymi skutkami stosowania przez organ egzekucyjny środków egzekucyjnych (środków przymusu). Jednak mogą pojawić się wątpliwości w zakresie skutków, jakie wywiera omawiana instytucja dobrowolnej zapłaty na uprawnienia pracownicze organów egzekucyjnych. Nie jest bowiem jasne, czy wpłaty dokonywane na podstawie projektowanego art. 67e będą składały się na tzw. kwotę uzyskaną, o której mowa w $\$ 1$ ust. 5 rozporządzenia Prezesa Rady Ministrów z 19 grudnia 2014 r. w sprawie uprawnień szczególnych przysługujących niektórym kategoriom członków korpusu służby cywilnej (Dz.U. 2015, poz. 30). Należy zauważyć, że kwota ta zgodnie z $\$ 1$ ust. 1 powyższego rozporządzenia stanowi podstawę do obliczania wynagrodzenia prowizyjnego przyznawanego członkowi korpusu służby cywilnej zatrudnionemu w komórce organizacyjnej egzekucji administracyjnej urzędu skarbowego.

Umożliwienie wierzycielowi uzyskania informacji o stanie majątkowym zobowiązanego przed wszczęciem postępowania egzekucyjnego (art. 37b u.p.e.a.) pozwoli na wcześniejszą ocenę stanu faktycznego (składników majątku ujętych w protokole) oraz możliwych do zastosowania środków egzekucyjnych. Regulacja ta wpisuje się w zasadę obowiązkowości w prowadzeniu egzekucji (art. 6 u.p.e.a.).

Z punktu widzenia efektywności postępowania egzekucyjnego pozytywnie należy ocenić możliwość zajęcia rzeczy ruchomej, o istnieniu której wiadomo $\mathrm{z}$ ewidencji prowadzonej przez zobowiązanego, z urzędowego rejestru ruchomości lub z rejestru zastawów (art. $98 \$$ la u.p.e.a.). Zajęcie powyższe będzie możliwe nawet wtedy, gdy, jak wskazano w uzasadnieniu do projektu ustawy (s. 93), ruchomość fizycznie nie znajduje się w miejscu zajęcia w chwili jego dokonywania.

Unormowanie, zgodnie z którym generowane automatycznie upomnienie, zawierające wezwanie do wykonania obowiązku z zagrożeniem skierowania sprawy do postępowania egzekucyjnego, może nie mieć podpisu pracownika organu (art. $15 \$ 1$ b u.p.e.a.), budzi wątpliwości. Należy stwierdzić, że upomnienie stanowi dokument urzędowy, z którego doręczeniem ustawa o postępowaniu egzekucyjnym w administracji wiąże skutki w postaci dopuszczalności wszczęcia egzekucji. Jak wynika z art. $77^{2}$ ustawy z 23 kwietnia 1964 r. - Kodeks cywil-

Opinia z 24 czerwca 2019 r. RL-033-17/19 o projekcie ustawy o zmianie ustawy o postępowaniu egzekucyjnym w administracji oraz niektórych innych ustaw, https://radalegislacyjna.gov.pl/dokumenty/opinia-z-24-czerwca-2019-r-o-projekcie-ustawy-o-zmianie-ustawy-o-postepowaniu-egzekucyjnym [dostęp 13 sierpnia 2019 r.]. 
ny (t.j. Dz.U. 2019, poz. 1145; dalej: k.c.), do zachowania dokumentowej formy czynności prawnej wystarcza złożenie oświadczenia woli w postaci dokumentu, $w$ sposób umożliwiajacy ustalenie osoby składającej oświadczenie. Jednakże na tle powyższego przepisu podnosi się w literaturze, że: strona, która powotuje się na oświadczenie woli złożone $w$ formie dokumentowej, musi w postępowaniu sqdowym wykazać tożsamość autora tego oświadczenia. Forma dokumentowa jako forma o najniższym stopniu sformalizowania ma - z założenia - przyczynić się do usprawnienia dokonywania czynności prawnych. Jednak to odformalizowanie dokonuje się $w$ dużym stopniu kosztem pewności obrotu prawnego, gdyż brak jest $w$ formie dokumentowej jednoznacznego elementu identyfikujacego osobę składająca oświadczenie woli ${ }^{4}$. Z uwagi na powyższe oraz na fakt, że zgodnie z powołanym przepisem Kodeksu cywilnego nie wykształciła się jednolita praktyka ani też linia orzecznicza, można podać $\mathrm{w}$ wątpliwość, czy $\mathrm{z}$ dokumentem pozbawionym jednoznacznego elementu identyfikującego pracownika wierzyciela ustawodawca powinien wiązać tak daleko idące skutki prawne.

Pozytywnie w kontekście interesów zobowiązanego należy ocenić także nałożony na organ egzekucyjny obowiązek uchylenia z urzędu czynności, gdy została ona dokonana $\mathrm{z}$ naruszeniem przepisów ustawy (art. 54b u.p.e.a.) oraz wyłączenie z egzekucji m.in. świadczeń „500+” oraz świadczeń alimentacyjnych, na wzór regulacji zawartej w przepisach dotyczących egzekucji sądowych (art. $80 \leqq 2 a$ u.p.e.a.).

Z punktu widzenia organów egzekucyjnych pozytywnie należy ocenić wprowadzenie zasady przekazywania tytułów wykonawczych drogą elektroniczną (art. 26 u.p.e.a.), co znacznie przyspieszy postępowanie. Dane zobowiązanego będą weryfikowane przez system teleinformatyczny, co oznacza, że organ egzekucyjny otrzyma jedynie prawidłowo wystawiony tytuł egzekucyjny.

Zgodne z zasadą gospodarnego prowadzenia egzekucji wydaje się uregulowanie, na mocy którego oddanie do sprzedaży komisowej lub do sprzedaży podmiotowi posiadającemu wymagane zezwolenie, koncesję albo wpis do rejestru działalności regulowanej następuje po cenie odpowiadającej co najmniej wartości szacunkowej nieruchomości (art. $105 \$ 3$ u.p.e.a.). Pozostaje to także w zgodzie $\mathrm{z}$ interesem zobowiązanego. Również zgodna $\mathrm{z}$ wymienioną zasadą jest regulacja nakładająca obowiązek zamieszczenia obwieszczenia o licytacji publicznej w Biuletynie Informacji Publicznej na stronie podmiotowej urzędu obsługującego organ egzekucyjny oraz przewidująca dodatkowo możliwość ogłoszenia w prasie lub w inny sposób, wedle uznania organu (art. 105a $₫ 3$ i $\$ 5$ u.p.e.a.). Obwieszczenie umieszczone $\mathrm{w}$ internecie zwiększy krąg zainteresowanych licytacją bez konieczności ponoszenia dodatkowych kosztów i będzie wiązało się jedynie z wygenerowaniem pisma. Obecnie obowiązujące unormowanie nakła-

4 S. Czepita i in., Komentarz do art. $77^{2}$ k.c. [w:] Prawo cywilne - część ogólna, red. Z. Radwański, 2019, Legalis. 
da na organ egzekucyjny obowiązek ogłaszania o licytacji przez obwieszczenie umieszczane (w formie papierowej) w co najmniej dwóch miejscach: w miejscu, gdzie ma się odbyć licytacja, oraz na tablicy ogłoszeń organu egzekucyjnego.

Ze względu na zasadę zaufania do państwa oraz stanowionego przezeń prawa przepis przejściowy pozostawiający w mocy dalsze tytuły wykonawcze, na podstawie których zabezpieczono należność pieniężną hipoteką przymusową, w tym hipoteką morską przymusową (art. 24 ustawy zmieniającej), należy ocenić jako zasadny.

\section{Podsumowanie}

W podsumowaniu należy stwierdzić, że projekt może być przedmiotem dalszych prac legislacyjnych.

Warto podkreślić, że nowelizacja zmienia obowiązujący model zgłaszania zarzutów w postępowaniu egzekucyjnym w administracji i rozszerza krąg podmiotów uprawnionych do sprzeciwu. Przyznaje również małżonkowi zobowiązanego uprawnienia zobowiązanego (w zakresie majątku wspólnego) oraz dłużnikowi rzeczowemu (w zakresie egzekucji z rzeczy ruchomej). Zawiera także liczne regulacje usprawniające oraz zwiększające efektywność postępowania egzekucyjnego w administracji.

Nową instytucją w postępowaniu egzekucyjnym w administracji jest m.in.: sprzedaż ruchomości przez zobowiązanego za zgodą organu egzekucyjnego oraz dobrowolna zapłata zobowiązanego. Jednak pojawiają się wątpliwości w zakresie skutków prawnych, jakie wywierać będzie instytucja dobrowolnej zapłaty na uprawnienia pracownicze organów egzekucyjnych.

Wątpliwości może budzić propozycja unormowania, zgodnie z którą w generowanym automatycznie upomnieniu zawierającym wezwanie do wykonania obowiązku z zagrożeniem skierowania sprawy do postępowania egzekucyjnego może nie być podpisu pracownika organu. Regulacje dotyczące podziału kwoty uzyskanej z egzekucji administracyjnej dostosowują procedurę egzekucyjną do wymogów prawa unijnego.

Do zmian korzystnych dla zobowiązanego należy wyłączenie z egzekucji m.in. świadczeń „500+”, na wzór regulacji zawartej w przepisach dotyczących egzekucji sądowej.

\section{Bibliografia}

Czepita S. i in., Komentarz do art. $77^{2}$ k.c. [w:] Prawo cywilne - część ogólna, red. Z. Radwański, 2019, Legalis. 